\title{
ROTHE'S METHOD FOR NONLINEAR PARABOLIC VARIATIONAL INEQUALITIES IN NONCYLINDRICAL DOMAINS
}

\author{
Gulchehra Kulieva And Komil Kuliev
}

\begin{abstract}
In this paper, a nonlinear parabolic variational inequality in noncylindrical domain is considered. Using extended Rothe's method recently achieved in [11] an approximate solution is constructed. Existence and uniqueness results are proved. Also, we present some further results and comments related to the main result.
\end{abstract}

Mathematics subject classification (2010): 65N40, 35K20.

Keywords and phrases: Parabolic variational inequalities, parabolic PDE, numerical method, timediscretization, Rothe's method.

\section{REFERENCES}

[1] I. Bock And J. KaČUR, Application of Rothe's Method to Parabolic Variational Inequalites, Math. Slovaca 31, 4 (1981), 429-436.

[2] J. DAsht, J. Engström, A. KUfNer And L.-E. Persson, Rothe's method for parabolic equations on non-cylindrical domains, Adv. Alg. Anal. 1, 1 (2006), 1-22.

[3] P. DrÁbeK, A. Kufner And F. Nicolosi, Quasilinear Elliptic Equations with Degenerations and Singularities, Walter de Gruyter \& Co., 1997.

[4] Essel, Emmanuel Kwame, Kuliev, Komil, Kulieva, Gulchehra and Persson, LarsERIK, On linear parabolic problems with singular coefficients in non-cylindrical domains, Int. J. Appl. Math. Sci. (IJAMS), 2008.

[5] Essel, Emmanuel Kwame, Kuliev, Komil, Kulieva, Gulchehra and Persson, LarsERIK, Homogenization of quasilinear parabolic problems by the method of Rothe and two scale convergence, Appl. Math. 4, 55 (2010), 305-327.

[6] J. KAČUR, Application of Rothe's method to perturbed linear hyperbolic equations and variational inequalities, Czech. Math. J. 34, (1984), 92-106.

[7] A. Kufner And S. Fučík, Nonlinear differntial equations, Elsevier Scientific Publishing Company, Amsterdam/Oxford/New York, 1980.

[8] A. Kufner, O. John And S. Fučík, Function Spaces, Publishing House of the Czechoslovak Academy of Sciences, 1977.

[9] A. KufNer, K. Kuliev AND G. Kulieva, The transformation method for non-cylindrical parabolic problems, Far East J. Math. Sci. (FJMS) 1, 28 (2008), 17-36.

[10] K. Kuliev, Parabolic Problems on Noncylindrical Domains - The Method of Rothe, Licentiate thesis, Department of Mathematics, Luleå University of Technology, 2006.

[11] K. KulieV And L.-E. Persson, An Extension of Rothe's Method to Non-cylindrical Domains, Appl. Math. 5, 52 (2007), 365-389 pp.

[12] G. Kulieva, Some special problems in elliptic and parabolic variational inequalities, Licentiate thesis Lulea University of Technology, ISSN 1402-1757; 2006:77, p. 105.

[13] J. L. Lions, Quelques méthodes de résolution des problémes aux limites non linéaires, Dunod Gauthier-Villars, Paris, 1969.

[14] K. REKTORYS, On application of direct variational methods to the solution of parabolic boundary value problems of arbitrary order in space variables, Czech. Math. J. 21, (1971), 318-339.

[15] K. ReKTorys, The Method of Discretization in Time and Partial Differential Equations, D. Reidel Publishing Company, 1982. 
[16] K. Rektorys, Variational Metods in Mathematics, Science and Engineering, D. Reidel Publishing Company, 1980. 